\title{
Exploring gender differences in the vulnerability towards drug abuse among adolescents in Malaysia
}

\author{
Wan Shahrazad Wan Sulaiman, ${ }^{1 *}$ Mohammad Rahim Kamaluddin, ${ }^{1}$ Ezarina Zakaria, ${ }^{1}$ \\ Fauziah Ibrahim, ${ }^{1}$ Nazirah Hassan, ${ }^{1}$ Jamiah Manap, ${ }^{1}$ Salina Nen, ${ }^{1}$ Zainah Ahmad Zamani, ${ }^{1}$ \\ Fatimah Yusooff ${ }^{2}$ \\ ${ }^{1}$ Centre for Research in Psychology and Human Well-Being, Faculty of Social Sciences and Humanities, Universiti \\ Kebangsaan Malaysia, Bangi, Selangor - Malaysia, ${ }^{2}$ Open University Malaysia, Petaling Jaya, Selangor -Malaysia
}

\begin{abstract}
Protective and risk factors are important issues to consider to reduce the vulnerability of adolescents to drug abuse. This study aims to determine the vulnerability to drug abuse in terms of gender differences in high-risk areas, based on statistics/data from the National Anti Narcotics Agency of Malaysia, namely in Sabak Bernam, Dungun, Johor Bahru, and Kuala Kedah. A survey method was employed, with 213 adolescents $(52.1 \%$ male, $47.9 \%$ female) who met the inclusion criteria completing the questionnaire. The questionnaire consisted of five aspects, namely demographic profile, interpersonal conflict, negative emotions, social support, and mental health. Data analysis was conducted using descriptive and inferential statistics. The results of the analysis show that there was no significant difference in aspects of interpersonal conflict $(\mathrm{t}=-0.556, \mathrm{p}>.05)$, negative emotions $(\mathrm{t}=0.131, \mathrm{p}>.05)$, or mental health by gender $(\mathrm{t}=-0.898, \mathrm{p}>.05)$. However, there was a significant difference in the aspect of social support $(\mathrm{t}=-2.046, \mathrm{p}<.05)$, with female subjects (37.13) showing a higher mean score than males (34.83). The findings of the study indicate that it is very important to understand the relevant factors so that drug abuse can be identified and prevented early on.
\end{abstract}

Keywords: gender; vulnerability; drug abuse

Abstrak: Faktor protektif dan faktor resiko adalah hal yang penting untuk dipertimbangkan dalam rangka mengurangi kerentanan remaja terhadap penyalahgunaan obat-obatan. Penelitian ini bertujuan untuk mengetahui kerentanan terhadap penyalahgunaan obat-obatan ditinjau dari perbedaan gender, pada wilayah beresiko tinggi berdasarkan Badan Nasional Anti Narkotika di Malaysia yaitu di Sabak Bernam, Dungun, Johor Bahru, dan Kuala Kedah. Penelitian ini menggunakan metode survey, sebanyak 213 orang remaja (52,1\% laki-laki, 47,9\% perempuan) yang memenuhi kriteria inklusi mengisi kuesioner. Kuesioner terdiri dari 5 aspek, yaitu: profil demografis, konflik interpersonal, emosi negatif, dukungan sosial, dan kesehatan mental. Analisis data menggunakan statistik deskriptif dan inferensial. Hasil analisis data menunjukkan bahwa tidak ada perbedaan yang signifikan pada aspek konflik interpersonal $(\mathrm{t}=-0,556, \mathrm{p}>0,05)$, emosi negatif $(\mathrm{t}=0,131, \mathrm{p}>0,05)$, dan kesehatan mental berdasarkan jenis kelamin $(\mathrm{t}=-0,898, \mathrm{p}>0,05)$. Namun demikian, terdapat perbedaan yang signifikan pada aspek dukungan sosial $(\mathrm{t}=-2,046, \mathrm{p}<0,05)$, di mana subjek perempuan $(37,13)$ menunjukkan rata-rata skor yang lebih tinggi dibandingkan subjek laki-laki $(34,83)$. Temuan penelitian ini menunjukkan bahwa sangat penting untuk mengetahui faktor yang relevan agar penyalahgunaan obat-obatan dapat diidentifikasi dan dicegah sejak dini.

Kata Kunci: gender; kerentanan; penyalahgunaan obat-obatan

\footnotetext{
*Corresponding Author: Wan Shahrazad Wan Sulaiman (shara@ukm.edu.my), Centre for Research in Psychology and Human Well-Being, Faculty of Social Sciences and Humanities, Universiti Kebangsaan Malaysia, 43600 Bangi, Selangor - Malaysia.
} 


\section{Introduction}

Drug addiction has been categorized as substance abuse in the Diagnostic and Statistical Manual of Mental Disorders 5 (American Psychiatric Association, 2013). Drug abuse is a problem that worries teachers, parents, and the community and is also considered a social problem (Jordan \& Andersen, 2017). Statistics for drug addiction in Malaysia show an increasing trend year on year, with the number of amphetamine addicts recording the highest total, with an increase from 12,089 in 2017 to 12,520 in 2018. The number of drug addicts in Malaysia in 2018 was also higher among males, at 125,320 (95.80\%); amongst those of Malay ethnicity, at 99,535 (99.34\%); and among adults aged 19-39 years, at $69.30 \%$. A report produced by the National Anti-Drugs Agency (N.A.D.A., 2018) shows that a total of 25,922 drug addicts were reported in 2017, with the average number of new drug addicts 18,440, while the number of repeat addicts or relapsed addicts was 7,482. N.A.D.A. (2018) also reported that the youngest client receiving treatment and rehabilitation in 2016 was just seven years old.

These statistics create concern among the community, as the effects of drug addiction cause various problematic behaviors and lead to crimes such as burglary, robbery, snatching, stealing, and gangsterism. Tomlinson, Brown, and Hoaken's (2016) study shows that aggressive behavior was influenced by drug abuse, particularly among adolescents using heroin and cocaine. A study conducted by Ólafsdóttir, Hrafnsdóttir, and Orjasniemi (2018) compared depression, anxiety, and stress between drug addicts and the normal population in Iceland. Their findings show that $36 \%$ or more of the drug addicts had average, serious, or very serious depression, anxiety, and/or stress. Depression, anxiety, and stress were also negatively correlated with quality of life. Moreover, drug use was also found to be associated with violence and crime. Håkansson and Jesionowska (2018) study found that there was a significant difference between perpetrators of violent crime with a lifetime history of substance use and all other criminal justice clients with substance use problems.

Therefore, the problem of drug abuse needs to be addressed by intensifying drug awareness and prevention programs in schools and communities. In Malaysia, individuals who are involved in drug addiction can be detained if their urine test is positive and can be sent to drug rehabilitation centers known as Cure \& Care Rehabilitation Centers (CCRC), which are under the purview of the National Anti-Drug Agency, Ministry of Home Affairs Malaysia. There are 22 such centers located in each state of Malaysia, which provide treatment, rehabilitation, and aftercare services to drug addicts to be free of drugs and lead their lives as normal individuals. Treatment and rehabilitation services are conducted in three settings: institutional-based treatment, community-based treatment and aftercare programs (N.A.D.A., 2018). However, it is not an easy task, as the relapse rate is very high, as evidenced from the 7,921 relapses in 2016 and 7,428 in 2017 (N.A.D.A., 2018).

There is no single factor that can identify whether an individual is susceptible to drug addiction; instead, studies show the role of various risk and protective factors influencing the predisposition for such behavior (N.I.D.A., 2014; Volkow, 2014). Studies identifying risk factors are very important, as they can provide information 
to parents and teachers regarding early detection if there are any changes in behavior that show a predisposition of adolescents to become addicted to drugs. These risk factors include physical, emotional, spiritual, and personality dysfunctions.

Previous studies have documented many types of risk factors. Among these are peer influence, stress, developmental changes, and negative role models (Roblyer, Betancourth \& Grzywacz, 2015; Smith, Vasquez, Emelogu, Hayes, Engebretson, \& Nash, 2020; Tam, Kwok, Lo, Lam \& Lee, 2018). Besides, discrimination, ethnic identity, access to drugs, and misperceptions about the risk of drugs (Verissimo, Gee, Ford, \& Iguchi, 2014; Zapolski, Clifton, Banks, Hershberger, \& Aalsma, 2017) have also been identified as risk factors. Changes in behavior and attitude (Volkow, 2014); exhibiting violent behavior (Tomlinson et al., 2016); and a decline in academic achievement, dropouts and school absence (Gubbels et al., 2019) also been reported to be related to drug addiction. N.I.D.A. (2014) also identifies other risk factors, such as aggressive behavior during childhood, lack of monitoring by parents, low social skills, experimenting with drugs, availability of drugs in schools, and poverty. On other hands, among the protective factors, are good self-control, parental support and monitoring, positive relationships, good academic achievement, anti-drug policies in schools, and neighborhood supervision and monitoring.

Based on the report by the Substance Abuse and Mental Health Services Administration (2014), equal numbers of boys and girls ages 1217 used illegal drugs. On the other hand, many studies have reported a significant difference in drug abuse behavior according to gender. For instance, Anderberg and Dahlberg (2018) and
Johnston, O'Malley, Miech, Bachman and Schulenberg (2015) found that substance abuse was higher among girls in early adolescence, while boys showed higher rates of abuse during late adolescence. Among the factors influencing drug use are peer and other social influences (Zapolski et al., 2019). The reasons for drug use among adolescent boys and girls can be to cope with mood changes, low self-esteem, or discomfort in social settings (Schwinn, Schinke, Hopkins, \& Thom, 2016).

Support for gender differences in drug addiction can be found in several previous studies. Becker, Perry, and Westenbroek (2012) and Perry, Westenbroek, and Becker (2013) state that biological sex differences can affect addictionlike behavior differently for males and females. This is consistent with other studies, which have found that within the general population, individuals differ in their risk of addiction due to a range of factors, including genetic and personality traits (Heinrich et al., 2016); experience of trauma or abuse (Kachadourian, Pilver, \& Potenza, 2014; Lieberman, Armeli, Scott, Kranzler, Tennen \& Covault, 2016; Mandavia, Robinson, Bradley, Ressler \& Powers, 2016); and sociocultural influences (Macleod, Hickman, Jones, Copeland, McKenzie, De Angelis, Kimber, \& Robertson, 2013).

Differences in negative emotions or affect can be observed among males and females. Women reported greater effects of drugs on mood and anxiety, as well as a greater stress response, compared to men (Becker, McClellan \& Reed, 2017). However, males exhibit greater withdrawal symptoms when quitting alcohol consumption than females (Becker et al., 2017). Women also might experience greater sensitivity to stress or the cues associated with a drug, and 
relapse can be triggered by these variables (Khazaee-Pool, Tahereh Pashaei, Roghayeh Nouri, Parvaneh Taymoori \& Koen Ponnet, 2019). Another risk factor is that a negative family environment can also predict substance use behavior. Becker et al. (2017) found that the environment and positive or negative experiences can also affect the brain and influence vulnerability to addiction differently in males and females. This is consistent with Macleod et al.'s (2013) study, which showed that family violence in childhood, especially directed against the child, was associated with increased risk of drug use for both males and females. In Wilson and Widom's (2009) study, abused and neglected girls were more likely than boys from comparable backgrounds to abuse illegal drugs as adults.

In terms of social support, men tended to show an inverse relationship between perceived social support and substance use frequency in socially stigmatized populations (Rapier, McKernan \& Stauffer, 2019). In addition, women who were addicted experienced greater stigma than men; this means that with less social support, women faced more isolation and a greater risk of relapse (Becker, McClellan, \& Reed, 2016). Findings from Bobzean, DeNobrega, and Perrotti, (2014) indicate that women tended to progress more rapidly than men from an initial drug experience to addiction, with regard to those who were vulnerable to addiction. Furthermore, women exhibited greater unpleasant symptoms than men during attempts to quit drug use (Becker et al., 2017; Becker \& Koob, 2016).

A study in Malaysia by Razali and Kliewer (2015) found that one in six adolescents and one in three young adults reported lifetime recreational and hard drug use, with greater use reported by males across all drug categories. They also reported that risk factors for lifetime recreational and hard drug use included early initiation of antisocial behavior, antisocial behavior amongst peers, and peer reinforcement of engaging in antisocial behavior; protective factors included religious practices and opportunities for prosocial school involvement. (Rodzlan et al., 2019), on the other hand, found that the risk factors for illicit drug use among Malaysian male adolescents were associated with younger age, rural school area, marital status of parents, being a current smoker, sexual experience, truancy, being involved in physical fights, and lack of peer support.

Based on the findings of previous studies, it is therefore crucial to explore vulnerability towards drug addiction by examining the risk and protective factors involved in drug abuse behavior. Examining the differences in these factors in males and females will also enable us to ascertain the treatment and rehabilitation needs suitable for them. Therefore, the objectives of the study are to examine gender differences in interpersonal conflict, negative emotions, social support, and mental health related to drug addiction among adolescents in Malaysia. Four hypotheses were formulated: (1) There is a significant difference in interpersonal conflict based on gender; (2) There is a significant difference in negative emotions based on gender; (3) There is a significant difference in social support based on gender; and (4) There is a significant difference in mental health based on gender.

\section{Method}

The study employed a survey research design by distributing questionnaires to adolescents who fulfilled the inclusion criteria. A total of 213 
adolescents participated by answering a set of questionnaires developed by the researchers. The respondents were chosen randomly in four hotspot areas identified by the National AntiDrugs Agency Malaysia, namely Sabak Bernam, Dungun, Johor Bahru, and Kuala Kedah.

The questionnaire used in the study comprised five parts: demographic profile, interpersonal conflict, negative emotions, social support, and mental health. Vulnerability to drug addiction is defined as the tendency to be involved in such addiction based on risk and protective factors. The risk factors were interpersonal conflict, which consisted of nine items, and negative emotions, which also comprised nine items. The protective factors were measured using social support (13 items) and mental health (12 items). The responses were measured on a four-point Likert scale, indicating 4=Strongly Agree, 3=Agree, 2=Disagree, and 1=Strongly Disagree. A pilot study was conducted with 50 respondents and reliability analysis showed that all four dimensions had satisfactory reliability, with a Cronbach's alpha of .616 for interpersonal conflict, .944 for negative emotions, .899 for social support, and .902 for mental health. Data from the actual study were then analyzed using descriptive and inferential statistics.

\section{Results}

\section{Demographic Profile}

The respondents' demographic profile is presented in Table 1. A total of 111 respondents (52.1\%) were male and 102 (47.9\%) were female. In terms of age range, 20 respondents (9.6\%) were aged 13; 33 (15.9\%) aged 14; 20
(9.6\%) aged 15; 74 (35.6\%) aged 16; 56 (26.9\%) aged 17; and five respondents (2.4\%) aged 18. A total of 69 respondents (32.4\%) came from Sabak Bernam, 60 (28.2\%) from Dungun, 68 (31.9\%) from Johor Bahru and 16 (7.5\%) were from Kuala Kedah. A total of 16 respondents (7.5\%) had family members who were involved in drug addiction, while the other 197 respondents (92.5\%) did not have any family members involved in drugs.

\section{Differences in Interpersonal Conflict, Negative}

Emotions, Social Support, and Mental Health based on Adolescents' Gender

The hypotheses on the differences in risk and protective factors based on gender were analyzed using a t test. Risk factors were measured using interpersonal conflict and negative emotions, while protective factors were measured using social support and mental health.

H1: There is a significant difference in interpersonal conflict based on gender.

The results in Table 2 show that there was no significant difference in interpersonal conflict based on gender, with $\mathrm{t}(211)=-0.565, \mathrm{p}>.05$. There was little difference in the mean scores, with males obtaining a mean score of 14.14 and females one of 14.59. Based on this result, hypothesis 1 was rejected.

H2: There is a significant difference in negative emotions based on gender.

The results also show that there was no significant difference in negative emotions based on gender, with $\mathrm{t}(211)=-1.517, \mathrm{p}>.05$. The mean score for male respondents was 15.18 and 16.52 for females. This result also means that hypothesis 2 was rejected. 
Table 1

Respondents' Demographic Profile

\begin{tabular}{llll}
\hline Demography & & Frequency & Percentage (\%) \\
\hline Gender & Male & 111 & 52.1 \\
& Female & 102 & 47.9 \\
Age & 13 yrs & 20 & 9.6 \\
& 14 yrs & 33 & 15.9 \\
& 15 yrs & 20 & 9.6 \\
& 16 yrs & 74 & 35.6 \\
& 17 yrs & 56 & 26.9 \\
Areas & 18 yrs & 5 & 2.4 \\
& Unspecified & 5 & - \\
& Sabak Bernam & 69 & 32.4 \\
& Dungun & 60 & 28.2 \\
Family members involved & Yes & 68 & 31.9 \\
with drug addiction & Johor Bahru & 16 & 7.5 \\
& Kuala Kedah & 16 & 7.5 \\
\hline
\end{tabular}

Table 2

Results of the Differences in Interpersonal Conflict, Negative Emotions, Social Support and Mental Health Based on Gender

\begin{tabular}{lllllll}
\hline Variable & Group & $\mathrm{N}$ & Mean & Std Dev & $\mathrm{T}$ & $\mathrm{p}$ \\
\hline Interpersonal & Male & 111 & 14.14 & 4.56 & -.556 & .579 \\
& Female & 102 & 14.59 & 6.78 & & \\
Negative & Male & 111 & 15.18 & 5.37 & -1.517 & .131 \\
emotions & Female & 102 & 16.52 & 7.28 & & \\
Social support & Male & 111 & 34.83 & 8.35 & -2.046 & .042 \\
& Female & 102 & 37.13 & 8.00 & & \\
Mental health & Male & 111 & 33.93 & 5.07 & -.898 & .371 \\
& Female & 102 & 34.75 & 7.800 & & \\
\hline
\end{tabular}

H3: There is a significant difference in social support based on gender.

The findings show that there was a significant difference in social support based on gender, with t $(211)=-2.046, p<.05$. Female respondents showed a higher value of 37.13 for social support, compared to the 34.83 of male respondents. Therefore, hypothesis 3 was accepted.

H4: There is a significant difference in mental health based on gender.

The results show no significant difference in mental health based on gender, with $\mathrm{t}$ (211) = 
-.898, p>.05. The mean score for male respondents was 33.93 and 34.75 for females. Therefore, hypothesis 4 was rejected.

\section{Discussion}

The dimension of interpersonal conflict in this study referred to the interaction of adolescents with their family, which is similar to the family environment construct in several other studies. The findings of this study were inconsistent with previous ones, such as Becker et al. (2017), who found that the environment and positive or negative experiences could also affect the brain and influence vulnerability to addiction differently in males and females. Macleod et al. (2013) and Wilson and Widom, (2009) also found that family violence in childhood and abuse were risk factors that made adolescents vulnerable to drug abuse. The inconsistent findings can be explained by the fact that both male and female respondents in this study were chosen from areas identified by the National Anti-Drugs Agency Malaysia as high risk for drug abuse, and as such many characteristics of the environment were similar for both genders, such as high-density populations and areas known to have easy access to drugs.

There was also no significant difference in negative emotions according to gender in this study. This contradicts findings from Becker et al. (2017), who reported that females showed greater effects of drugs on mood and anxiety, as well as a greater stress response, compared to males. As this study focused on adolescents, it can be said that this finding of no significant difference can be attributed to the fact that both male and female adolescents were at the same physical, emotional, and psychological stages of development, thus experiencing similar vulnerability towards drug use. This is supported by several studies that indicate that both genders exhibit similar addiction-like behavior (Becker et al., 2012; Carroll, Collins, Kohl, Johnson, \& Dougen, 2016).

The results of this study are also consistent with those of Bliton, Wolford-Clevenger, Zapor, Elmquist, Brem, Shorey, and Stuart (2016), who found no significant gender difference in emotional dysregulation. This is due to the fact that females behave similarly to males when they experience weakened or uncomfortable emotions; that is, both behave aggressively to regulate their emotions in a maladaptive way. Both males and females experience emotional dysregulation in their difficulty to control their impulses; lack awareness of emotional regulation strategies; reject emotional responses; and lack emotional clarity when faced with unfavorable emotions.

There was also no significant difference in mental health based on gender. This is also inconsistent with the meta-analytical study conducted by Silva et al. (2020) on 43 studies involving adolescents between the ages of 10 and 19 years old. The results of their study indicated that mental health affected girls more, which can be attributed to permanent concerns with their physical appearance, body dissatisfaction and exposure to sexualization. Although the age group of the respondents in this study was similar, there was no significant difference in mental health between the males and females, indicating that they experienced similar states of such health due to their similar demographic backgrounds.

Finally, the results indicate a significant difference in social support based on gender, with female respondents showing higher social support scores. This result is consistent with the study of Camara et al. (2017), who found gender differences in perceived social support, with girls 
perceiving higher levels of support from classmates and close friends than boys. In addition, girls reported significantly more support from close friends than any other source, whereas boys reported significantly less support from classmates. This is supported by Rickwood et al.'s (2005) study, which showed most young people talk to friends or family members as the first step in seeking support. Sulaiman et al. (2013) also concur with this, stating that adolescents still need social support from family and peers, even when they move towards achieving independence in adulthood.

\section{Conclusion}

This study has shown that there are no significant differences in interpersonal conflict, negative emotions, and mental health between male and female adolescents, but a difference was observed in relation to social support. The consequences of this finding indicate that more social support needs to be given to male adolescents to prevent them from becoming involved in drug abuse. The nonsignificant findings may be due to certain limitations of the study, such as the homogeneity of the characteristics of the respondents, who were chosen from hotspot areas identified by the National Anti-Drugs Malaysia. These areas are known to be densely populated, with easy access to drugs. Moreover, the distribution of the questionnaires was made randomly at schools in identified areas, without the benefit of the researchers explaining the items in the questionnaire for those who did not fully understand the meaning of them.

Adolescence is a challenging phase for individuals, both males and females. They need a supporting environment, such as strong family relationship, positive peer influence and good role models. These can provide them with protective factors to prevent them from becoming involved in risky behavior.

Although treatment and rehabilitation programs for drug addicts are provided through institutional-based treatment, community-based treatment and aftercare programs, these cater for all ages. There is a need for treatment and rehabilitation modules specifically for adolescents, which take into account their physical, emotional, and psychological development, as well as the role of risk and protective factors. In addition, current prevention efforts must be targeted at the individual level, focusing on enhancing overall socio-emotional competency skills such as problem solving, decision making, goal setting, peer refusal, communication, coping, and self-efficacy.

\section{Acknowledgements}

The researchers would like to express gratitude to the National Anti-Drug Agency Malaysia for funding the research. The project was also approved by the National Anti-Drug Agency Malaysia Steering Committee in terms of the involvement of respondents in hotspot areas (Approval Ref Code: SK-2019-026).]

\section{References}

Anderberg, M., \& Dahlberg, M. (2018). Gender differences among adolescents with substance abuse problems at Maria clinics in Sweden. Nordic Studies on Alcohol and Drugs, 35(1), 24-38. https://doi.org/10.1177/1455072517751263 
Association, A. P. (2013). Diagnostic and statistical manual of mental disorders (DSM-5®). American Psychiatric Pub.

Becker, J. B., \& Koob, G. F. (2016). Sex differences in animal models: Focus on addiction. Pharmacological Reviews, 68(2), 242-263. https://doi.org/10.1124/pr.115.011163

Becker, J. B., McClellan, M. L., \& Reed, B. G. (2017). Sex differences, gender and addiction. Journal of Neuroscience Research, 95(1-2), 136-147. https://doi.org/10.1002/jnr.23963

Becker, J. B., McClellan, M., \& Reed, B. G. (2016). Sociocultural context for sex differences in addiction. Addiction Biology, 21(5), 1052-1059. https://doi.org/10.1111/adb.12383

Becker, J. B., Perry, A. ., \& Westenbroek, C. (2012). Sex differences in the neural mechanisms mediating addiction: A new synthesis and hypothesis. Biology of Sex Differences, 3(1), 14. https://doi.org/10.1186/2042-6410-3-14

Bliton, C. F., Wolford-Clevenger, C., Zapor, H., Elmquist, J., Brem, M. J., Shorey, R. C., \& Stuart, G. L. (2016). Emotion dysregulation, gender, and intimate partner violence perpetration: An exploratory study in college students. Journal of Family Violence, 31(3), 371-377. https://doi.org/10.1007/s10896-015-9772-0

Bobzean, S. A. M., DeNobrega, A. K., \& Perrotti, L. I. (2014). Sex differences in the neurobiology of drug addiction. Experimental Neurology, 259, 64-74. https://doi.org/10.1016/j.expneurol.2014.01.022

Camara, M., Bacigalupe, G., \& Padilla, P. (2017). The role of social support in adolescents: Are you helping me or stressing me out? International Journal of Adolescence and Youth, 22(2), 123-136. https://doi.org/10.1080/02673843.2013.875480

Carroll, M. E., Collins, M., Kohl, E. A., Johnson, S., \& Dougen, B. (2016). Sex and menstrual cycle effects on chronic oral cocaine self-administration in rhesus monkeys: Effects of a nondrug alternative reward. Psychopharmacology, 233(15-16), 2973-2984. https://doi.org/10.1007/s00213-016-4343-5

Gubbels, J., van der Put, C. E., \& Assink, M. (2019). Risk factors for school absenteeism and dropout: A meta-analytic review. Journal of Youth and Adolescence, 48(9), 1637-1667. https://doi.org/10.1007/s10964-019-01072-5

Håkansson, A., \& Jesionowska, V. (2018). Associations between substance use and type of crime in prisoners with substance use problems: A focus on violence and fatal violence. Substance Abuse and Rehabilitation, 9, 1-9. https://doi.org/10.2147/SAR.S143251

Heinrich, A., Müller, K. U., Banaschewski, T., Barker, G. J., Bokde, A. L. W., Bromberg, U., Büchel, C., Conrod, P., Fauth-Bühler, M., Papadopoulos, D., Gallinat, J., Garavan, H., Gowland, P., Heinz, A., Ittermann, B., Mann, K., Martinot, J.-L., Paus, T., Pausova, Z., ... Nees, F. (2016). Prediction of alcohol drinking in adolescents: Personality-traits, behavior, brain responses, and genetic variations in the context of reward sensitivity. Biological Psychology, 118, 79-87. https://doi.org/10.1016/j.biopsycho.2016.05.002

Johnston, L. D., O'Malley, P. M., Miech, R. A., Bachman, J. G., \& Schulenberg, J. E. (2015). Monitoring the future national survey results on drug use: 1975-2014: Overview, key findings on adolescent drug use. Institute for Social Research, The University of Michigan.

Jordan, C. J., \& Andersen, S. L. (2017). Sensitive periods of substance abuse: Early risk for the transition to dependence. Developmental Cognitive Neuroscience, 25, 29-44. https://doi.org/10.1016/j.dcn.2016.10.004 
Kachadourian, L. K., Pilver, C. E., \& Potenza, M. N. (2014). Trauma, PTSD, and binge and hazardous drinking among women and men: Findings from a national study. Journal of Psychiatric Research, 55, 35-43. https://doi.org/10.1016/j.jpsychires.2014.04.018

Khazaee-Pool, M., Pashaei, T., Nouri, R., Taymoori, P., \& Ponnet, K. (2019). Understanding the relapse process: exploring Iranian women's substance use experiences. Substance Abuse Treatment, Prevention, and Policy, 14(1), 27. https://doi.org/10.1186/s13011-019-0216-3

Lieberman, R., Armeli, S., Scott, D. M., Kranzler, H. R., Tennen, H., \& Covault, J. (2016). FKBP5 genotype interacts with early life trauma to predict heavy drinking in college students. American Journal of Medical Genetics Part B: Neuropsychiatric Genetics, 171(6), 879-887. https://doi.org/10.1002/ajmg.b.32460

Macleod, J., Hickman, M., Jones, H. E., Copeland, L., McKenzie, J., De Angelis, D., Kimber, J., \& Robertson, J. R. (2013). Early life influences on the risk of injecting drug use: case control study based on the Edinburgh Addiction Cohort. Addiction, 108(4), 743-750. https://doi.org/10.1111/add.12056

Mandavia, A., Robinson, G. G. N., Bradley, B., Ressler, K. J., \& Powers, A. (2016). Exposure to childhood abuse and later substance use: Indirect effects of emotion dysregulation and exposure to trauma. Journal of Traumatic Stress, 29(5), 422-429. https://doi.org/10.1002/jts.22131

N.A.D.A. (2018). Maklumat Dadah Agensi Anti Dadah Kebangsaan, Kementerian Dalam Negeri. National Anti-Drugs Agency Drug Information, Ministry of Home Affairs.

N.I.D.A. (2014). Principles of substance abuse prevention for early childhood. National Institute on Drug Abuse.

Ólafsdóttir, J., Hrafnsdóttir, S., \& Orjasniemi, T. (2018). Depression, anxiety, and stress from substanceuse disorder among family members in Iceland. Nordic Studies on Alcohol and Drugs, 35(3), 165-178. https://doi.org/10.1177/1455072518766129

Otiniano Verissimo, A. D., Gee, G. C., Ford, C. L., \& Iguchi, M. Y. (2014). Racial discrimination, gender discrimination, and substance abuse among Latina/os nationwide. Cultural Diversity and Ethnic Minority Psychology, 20(1), 43-51. https://doi.org/10.1037/a0034674

Perry, A. N., Westenbroek, C., \& Becker, J. B. (2013). The development of a preference for cocaine over food identifies individual rats with addiction-like behaviors. PLOS ONE, 8(11), e79465. https://doi.org/10.1371/journal.pone.0079465

Rapier, R., McKernan, S., \& Stauffer, C. S. (2019). An inverse relationship between perceived social support and substance use frequency in socially stigmatized populations. Addictive Behaviors Reports, 10, 100188. https://doi.org/10.1016/j.abrep.2019.100188

Razali, M. M., \& Kliewer, W. (2015). Risk and protective factors for recreational and hard drug use among Malaysian adolescents and young adults. Addictive Behaviors, 50, 149-156. https://doi.org/10.1016/j.addbeh.2015.06.022

Rickwood, D., Deane, F. P., Wilson, C. J., \& Ciarrochi, J. (2005). Young people's help-seeking for mental health problems. Australian E-Journal for the Advancement of Mental Health, 4(3), 218-251. https://doi.org/10.5172/jamh.4.3.218

Roblyer, M. I. Z., Betancourth, S., \& Grzywacz, J. G. (2015). Risk and protective factors for lifetime marijuana use among Colombian emergent adults attending college. ISSBD Bulletin, 2015(1), 5.

Rodzlan Hasani, W. S., Miaw Yn, J. L., Saminathan, T. A., Robert Lourdes, T. G., Ramly, R., Abd Hamid, H. A., Ismail, H., Abd Majid, N. L., Mat Rifin, H., Awaluddin, S. M., \& Mohd Yusoff, M. F. (2019). Risk factors for illicit drug use among Malaysian male adolescents. Asia Pacific Journal of Public Health, 31(8_suppl), 48S-56S. https://doi.org/10.1177/1010539519865053 
Schwinn, T. M., Schinke, S. P., Hopkins, J., \& Thom, B. (2016). Risk and protective factors associated with adolescent girls' substance use: Data from a nationwide Facebook sample. Substance Abuse, 37(4), 564-570. https://doi.org/10.1080/08897077.2016.1154495

Silva, S. A., Silva, S. U., Ronca, D. B., Gonçalves, V. S. S., Dutra, E. S., \& Carvalho, K. M. B. (2020). Common mental disorders prevalence in adolescents: A systematic review and meta-analyses. PLOS ONE, 15(4), e0232007. https://doi.org/10.1371/journal.pone.0232007

Smith, N. Z., Vasquez, P. J., Emelogu, N. A., Hayes, A. E., Engebretson, J., \& Nash, A. J. (2020). The good, the bad, and recovery: Adolescents describe the advantages and disadvantages of alternative peer groups. Substance Abuse: Research and Treatment, 14, 117822182090935. https://doi.org/10.1177/1178221820909354

Sulaiman, W. S. W., Kadir, N. B. A., Halim, F. W., Omar, F., Latiff, R. A., \& Sulaiman, W. S. W. (2013). Structural relations between personality traits, coping strategy, social support and well-being among adolescents. Pertanika Journal of Social Science and Humanities, 21(5), 121-134.

Tam, C. H., Kwok, S. I., Lo, T. W., Lam, S. H., \& Lee, G. K. (2018). Hidden drug abuse in Hong Kong: From social acquaintance to social isolation. Frontiers in Psychiatry, 9, 457. https://doi.org/10.3389/fpsyt.2018.00457

Tomlinson, M. F., Brown, M., \& Hoaken, P. N. S. (2016). Recreational drug use and human aggressive behavior: A comprehensive review since 2003. Aggression and Violent Behavior, 27, 9-29. https://doi.org/10.1016/j.avb.2016.02.004

U.S. Department of Health and Human Services. (2014). Results from the 2013 National Survey on Drug Use and Health: Summary of National Findings. Substance Abuse and Mental Health Services Administration.

https://www.samhsa.gov/data/sites/default/files/NSDUHresultsPDFWHTML2013/Web/NS DUHresults2013.pdf

Volkow, N. (2014). Harnessing the power of science to inform substance abuse and addiction policy and practice. Presented Paper. House Committee on Appropriations Subcommittee on Commerce, Justice, Science and Related Agencies. National Institue on Drug Abuse.

Wilson, H. W., \& Widom, C. S. (2009). A prospective examination of the path from child abuse and neglect to illicit drug use in middle adulthood: The potential mediating role of four risk factors. Journal of Youth and Adolescence, 38(3), 340-354. https://doi.org/10.1007/s10964-008-93316

Zapolski, T. C. B., Clifton, R. L., Banks, D. E., Hershberger, A., \& Aalsma, M. (2019). Family and peer influences on substance attitudes and use among juvenile justice-involved youth. Journal of Child and Family Studies, 28(2), 447-456. https://doi.org/10.1007/s10826-018-1268-0

Zapolski, T. C. B., Fisher, S., Banks, D. E., Hensel, D. J., \& Barnes-Najor, J. (2017). Examining the protective effect of ethnic identity on drug attitudes and use among a diverse youth population. Journal of Youth and Adolescence, 46(8), 1702-1715. https://doi.org/10.1007/s10964-016-0605-0 
This page has been intentionally left blank. 